\title{
Pendampingan Pembelajaran Online menggunakan Edmodo bagi Siswa Kelas 9 SMP Muhammadiyah 6 Semarang
}

\author{
Yani Parti Astuti*1, Egia Rosi Subhiyakto ${ }^{2}$, Liya Umaroh ${ }^{3}$ \\ 1,2,3 Jurusan Teknik Informatika, Universitas Dian Nuswantoro \\ E-mail:*11yanipartiastuti@dsn.dinus.ac.id, ${ }^{2}$ egia.rosi.subhiyakto@dsn.dinus.ac.id, \\ 1iya.umaroh@dsn.dinus.ac.id
}

\begin{abstract}
Abstrak
Dalam pendidikan siswa mempunyai peranan yang sangat penting bagi sekolah. Siswa yang kreatif dan inovatif akan membawa nama baik dan kemajuan sekolah. Untuk itu, selain mendapatkan pendidikan formal, siswa harus bisa memanfaatkan teknologi dengan optimal. Sehingga setiap siswa mampu berkompetensi dengan dunia luar dan mempunyai bekal yang mapan untuk melanjutkan pendidikan ke jenjang yang lebih tinggi.Mengingat situasi saat ini yang mana dunia dipusingkan dengan wabah pandemi covid-19, siswa sekolah juga pusing dengan adanya sistem pendidikan dari rumah. Pendidikan dari rumah bukan berarti siswa hanya belajar sendiri, tetapi siswa diharapkan mampu berinteraksi dengan guru dan siswa lain menggunakan internet. Sistem ini dinamakan e-learning atau media pendidikan dengan internet. Dalam kenyataannya banyak siswa yang belum paham dengan e-learning khususnya siswa SMP. Adapun sekolah yang menjadi objek Program Kemitraan Masyarakat (PKM) dalam rangka pengabdian masyarakat ini adalah SMP Muhammadiyah 6 Semarang yang beralamat Jl. Brotojoyo II no 22, Panggung Kidul Kec. Semarang Utara Semarang. Pengabdian ini diharapkan dapat memberikan pemahaman dan pendampingan penerapan e-Learning menggunakan edmodo bagi siswa - siswa SMP Muhammadiyah 6 Semarang. Dan akhirnya bisa menciptakan pembelajaran yang lebih interaktif dan mampu meningkatkan motivasi siswa.
\end{abstract}

Kata kunci: Edmodo, e-Learning, pandemi

\begin{abstract}
In education, students have a very important role for schools. Creative and innovative students will bring good name and progress to the school. For this reason, besides getting formal education, students must make optimal use of technology. So that every student is able to compete with the outside world and have an established provision to continue their education to a higher level. Given the current situation where the world is confused with the Covid-19 pandemic outbreak, school students are also recognized by the existence of an education system from home. Education from home does not mean students only learn themselves, but students are expected to be able to work with teachers and other students using the internet. This system is called e-learning or educational media with the internet. In fact, many students do not understand e-learning, especially junior high school students. The school that is the object of the Community Partnership Program (PKM) in the context of community service is SMP Muhammadiyah 6 Semarang, having its address at Jl. Brotojoyo II no 22, Panggung Kidul Kec. North Semarang Semarang. This service is expected to provide understanding and assistance in implementing e-Learning using edmodo for students of SMP Muhammadiyah 6 Semarang. And finally it can create more interactive learning and can increase student motivation.
\end{abstract}

Keywords: Edmodo, e-Learning, Pandemic 


\section{PENDAHULUAN}

Berdasarkan Undang - undang No 20 tahun 2015 yang berisi tentang Sistem Pendidikan Nasional bahwa pengertian Pendidikan adalah usaha yang sadar dan terencana untuk mewujudkan suasana belajar dan proses pembelajaran dengan maksud mengembangkan potensi peserta didik hingga berguna bagi masyarakat, bangsa dan Negara. Sedang visi pendidikan adalam untuk mewujudkan sistem pendidikan menjadi perantara sosial bagi warga Negara Indonesia agar bisa berkembang menjadi insan yang berkualitas.

Untuk mendukung sistem pendidikan yang ada di Indonesia maka pada lembaga pendidikan khususnya sekolah menerapkan berbagai macam media pembelajaran. Salah satu media pembelajaran yang diterapkan di sekolah adalah media pembelajaran berbasis internet. Media pembelajaran berbasis internet disebut juga e-learning[3], yaitu suatu media pembelajaran yang memadukan penggunaan teknologi internet. Dengan memanfaatkan elearning diharapkan mampu meningkatkan hasil dari belajar siswa yang menjadi tambahan, pelengkap, pengganti pembelajaran konvensional[4][5].

Seperti pada situasi yang terjadi pada akhir tahun 2019 sampai tahun 2020 yang mana dunia telah digemparkan dengan adanya wabah virus corona atau dikenal dengan covid-19. Dalam hal ini sistem pendidikan semuanya beralih pada e-learning, karena tidak dimungkinkan untuk sistem pembelajaran konvensional (tatap muka). Hal ini karena wabah ini akan menyebar cepat jika masyarakat berkerumun atau berkelompok termasuk pada kegiatan sekolah. Semua siswa belajar dari rumah dan ujian juga dari rumah. Untuk itu sangat penting bagi seluruh siswa mengenal adanya e-learning yang telah diuraikan di atas.

Dengan e-learning sebagai media pembelajarannya, maka siswa dapat belajar tidak terbatas oleh ruang dan waktu[6]. Hal ini dikarenakan semua materi, grup diskusi, latihan soal berada pada suatu media di internet yang dapat diakses yang kapanpun dan dimanapun. Pencarian informasi juga akan lebih cepat dibanding ketika pencarian informasi pada buku. Sehingga siswa tidak perlu membeli buku, mengingat harga buku semakin mahal. Salah satu teknologi informasi dari e-learning salah satunya adalah Edmodo. Edmodo akan memberi perubahan yang berarti dalam penyampaian pelaksanaan proses instruksional dan pembelajaran. Edmodo juga mampu memberikan tata kelola pembelajaran yang mudah dan juga memiliki fasilitas kelas digital dan komunitas pembelajaran yang efektif[6][7].

Berdasarkan uraian di atas, maka penerapan e-learning sangat diperlukan di semua sekolah. Bahkan tidak memandang jenjang yaitu bisa dari SD, SMP, dan juga SMA/SMK. Pemahaman mengenai e-Learning di sekolah akan mengarah kepada implementasi e-Learning di sekolah tersebut. Dalam hal ini harus seimbang antara guru dan siswa dalam pelaksanaannya. Adapun sekolah yang menjadi objek pada Program Kemitraan Masyarakat (PKM) adalah SMP Muhammadiyah 6 Semarang yang beralamat di Jl. Brotojoyo II no 22, Panggung Kidul Kec. Semarang Utara. Berdasarkan lokasi SMPN Muhammadiyah 6 Semarang terletak di kota Semarang sehingga jaringan internet memiliki sinyal yang kuat untuk implementasi penggunaan e-Learning. Pengabdian ini diharapkan dapat memberikan pemahaman dan pendampingan penggunaan e-Learning pada siswa - siswa SMP Muhammadiyah 6 Semarang. Sehingga siswa bisa lebih interaktif dan mandiri dalam belajar segala materi - materi sekolah yang relevan.

\section{METODE PENELITIAN}

Pelaksanaan pengabdian diawali dengan survey ke tempat pengabdi yaitu di SMP Muhammadiyah 6 Semarang. Ibu Kepala Sekolah Srie Rahayu, S.Pd menerima tim pengabdi dengan ramah dan sangat antusias. Tim pengabdi mengemukakan program yang akan diberikan pada siswa - siswa kelas 9 di SMP tersebut. Semua ini diberikan berdasarkan latar belakang yang telah terjadi di masa pandemi sekarang ini. Mengetahui hal tersebut, maka Ibu kepala sekolah langsung menyetujui program yang tim pengabdi tawarkan. Program yang ditawarkan adalah pendampingan pada siswa kelas 9 mengenai Pembelajaran online dengan edmodo. Tim pengabdi memberikan metode yang akan dilakukan, yaitu : 


\section{Analisa \& Menentukan Masalah}

\section{Menetapkan Tujuan}

\section{Merancang Materi}

\section{Pelaksanaan Pendampingan pada siswa}

\section{Analisa Hasil Pelatihan}

\section{Pelaporan}

Gambar 1 Metode Pengabdian

Setelah program disetujui, maka langkah pertama mengajukan surat kesediaan mitra pada program tersebut. Langkah berikutnya menunggu program disetujui oleh pihak LPPM Udinus. Sesudah program disetujui maka tim pengabdi selalu koordinasi dengan pihak sekolah tentang pelaksanaannya. Mengingat pandeemi tidak kunjung berakhir, maka pelaksanaan program tidak bisa diikuti oleh semua siswa. Metode pelaksanaan yang diberikan adalah sebagai berikut :

1. Setiap siswa harus mempunyai akun

2. Pelaksanaan dilakukan di lab sekolah dengan protokol kesehatan

3. Adanya koneksi internet di sekolah

4. Siswa bisa mendaftar dan login ke edmodo

5. Siswa bisa masuk kelas pembelajaran online edmodo

Metode yang disampaikan di atas harus bisa dilakukan setiap siswa yang ikut pelatihan. Diharapkan pelatihan ini bisa berlanjut sampai setiap siswa lancar menggunakan edmodo dan bisa mengaplikasikannya setelah lulus dari SMP Muhammadiyah 6 Semarang.

\section{HASIL DAN PEMBAHASAN}

Ada beberapa hasil yang dicapai pada pengabdian ini, diantaranya adalah sebagai berikut: 1. Siswa mengenal tentang pembelajaran online edmodo

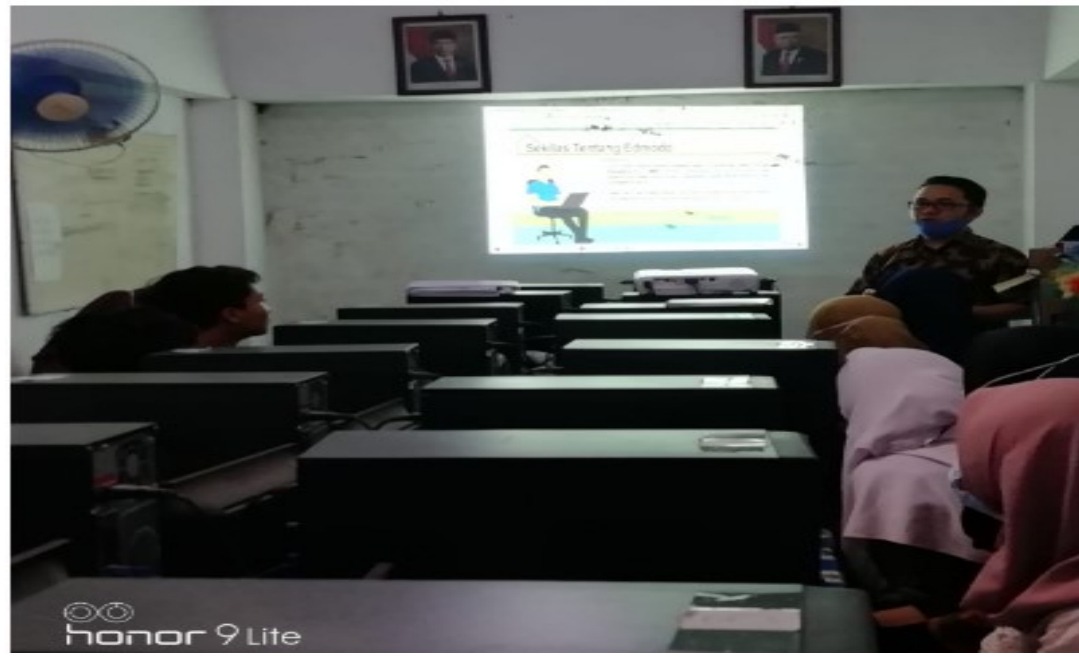

Gambar 2 Mengenalkan Emodo pada siswa kelas 
Pada gambar 2 menjelaskan pada siswa tentang pengertian edmodo dan langkah awal untuk mengoperasikan edmodo. Siswa dihimbau untuk mempunyai akun agar bisa menuju langkah beriktnya yaitu login ke edmodo.

2. Siswa mampu login ke edmodo

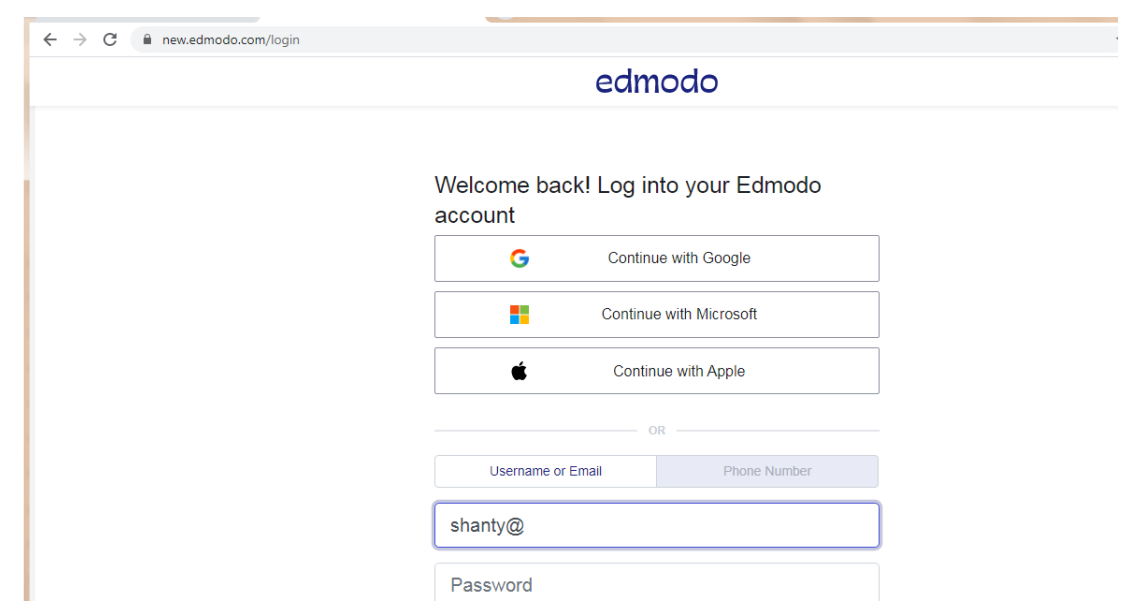

Gambar 3 Siswa masuk ke alamat edmodo

Setelah semua siswa mempunyai akun, maka siswa bisa mulai membuka edmodo dan login sesuai akun masing - masing siswa. Tidak banyak siswa yang bisa login ke edmodo. Hal ini karena masih minimnya pengetahuan siswa tentang penggunaan software.

3. Siswa diberi tugas pada pembelajaran edmodo

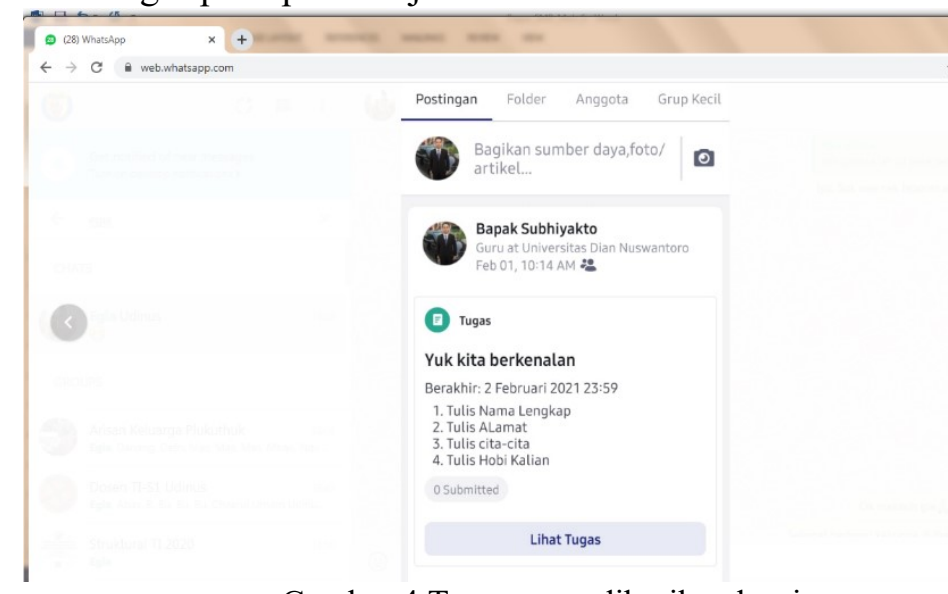

Gambar 4 Tugas yang diberikan ke siswa

Pada gambar 4 menunjukkan bahwa siswa diharapkan untuk bisa mengerjakan tugas yang diberikan oleh instruktur pengabdian.

4. Siswa mampu mengerjakan tugas yang diberikan

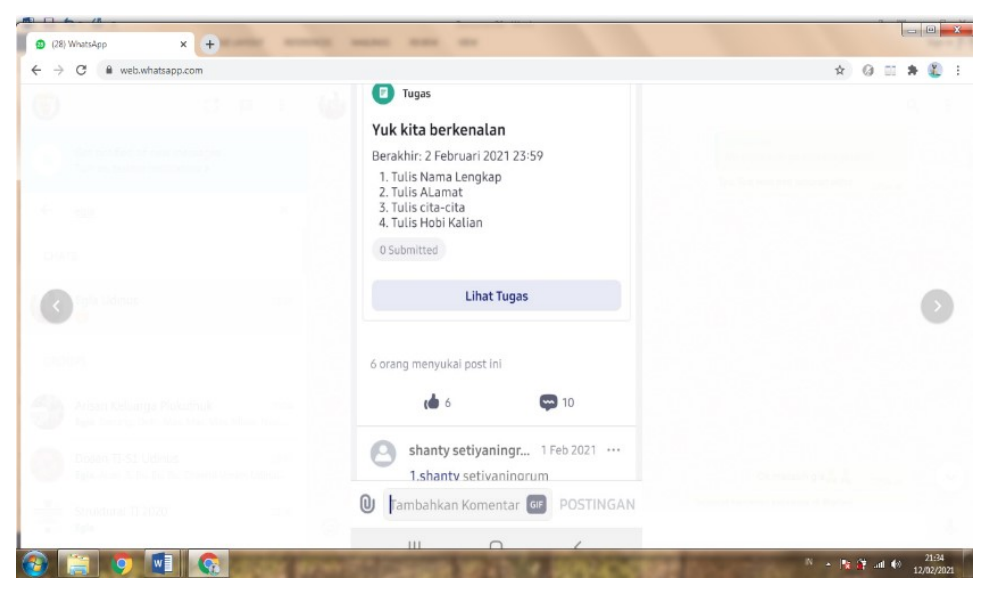


Gambar 5 Siswa yang sudah mengumpulkan tugas

Dari gambar 5 siswa mulai proses dalam pengumpulan tugas yang diberikan. Pada fase ini diharapkan semua siswa bisa mengumpulkan tugas sesuai dengan waktu yang telah diberikan.

5. Siswa diperlihatkan yang belum mengumpulkan

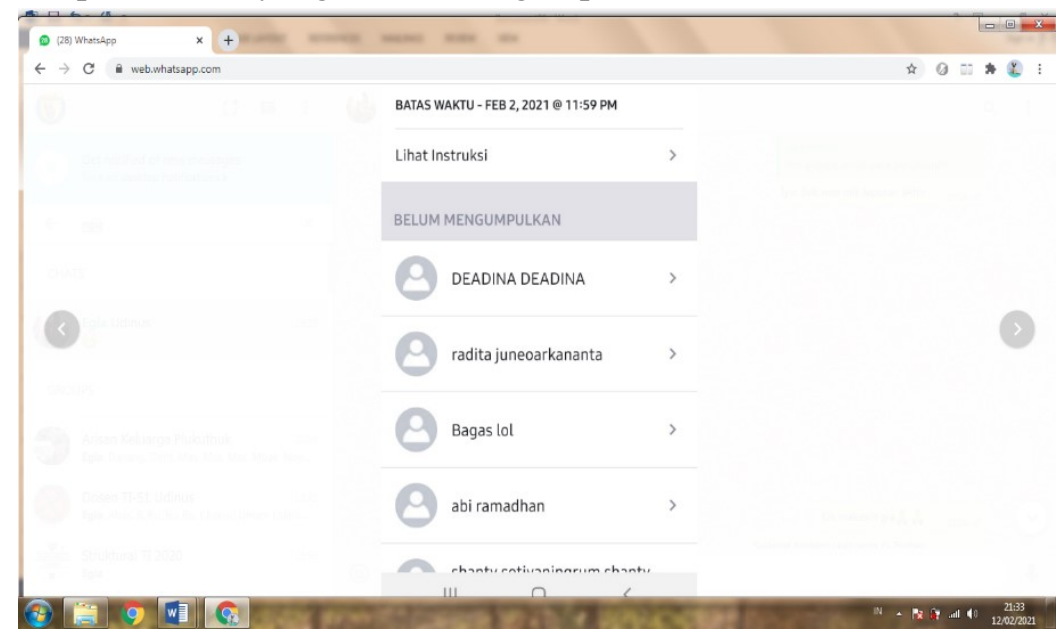

Gambar 6 siswa yang belum mengumpulkan tugas

Langkah terakhir, siswa diperlihatkan ada berapa siswa yang sudah mengumpulkan tugas dan yang belum mengumpulkan tugas. Sehingga siswa yang belum terlihat, mereka segera melakukan pengumpulan tugasnya hingga setiap siswa terlihat pada daftar pengumpulan tugas.

Pada pengabdian ini didapat luaran sebagai berikut :

1. Mengunggah kegiatan pengabdian ke dalam youtube dengan alamat https://youtu.be/1nR4AKDPHk8

Dengan Judul : Abdimasku Pendampingan Pembelajaran Online Menggunakan Edmodo bagi Siswa Kelas 9 SMP Muhammadiyah 6

2. Menghasilkan artikel yang diunggah di jurnal pengabdian

3. Menghasilkan bahan ajar berupa PPT yang siap digunakan untuk belajar dan mempraktekkannya

\section{KESIMPULAN DAN SARAN}

\subsection{Kesimpulan}

Pada pengabdian ini dapat diambil suatu kesimpulan sebagai berikut

1. Pembelajaran online dengan edmodo bisa dipelajari dengan mudah dan bisa mendaftar dan login dengan akun yang sudah dipunyai

2. Pembelajaran online dengan edmodo telah memberikan pengetahuan kepada siswa SMP Muhammadiyah 6 Semarang dan bisa menjadi bekal dalam pembelajaran online di musim pandemi

\subsection{Saran}

Setiap kegiatan pasti ada kekurangannya. Begitupun dalam kegiatan pengabdian ini. Dalam kegiatan ini masih belum optimal dalam mengenalkan pembelajaran online dengan edmodo secara maksimal. Untuk itu di lain waktu bisa adanya follow up atau tindak lanjut agar 
pengetahuan siswa bisa lebih optimal. Dan siswa benar - benar bisa memahami tentang edmodo.

\section{UCAPAN TERIMA KASIH}

Pengabdian masyarakat ini terlaksana berkat bantuan dana dari LPPM Udinus Semarang. Untuk itu dalam tulisan ini kami mengucapkan terima kasih kepada LPPM Udinus Semarang, Team Pengabdi, Semua pihak yang telah mendukung kegiatan ini terutama seluruh karyawan dan guru serta kepala sekolah SMP Muhammadiyah 6 Semarang. Tak lupa saya ucapkan kepada mahasiswa yang telah membantu kegiatan ini.

\section{DAFTAR PUSTAKA}

[1] UU No 14 Tahun 2005 tentang Guru dan Dosen

[2] https://kominfo.go.id/index.php/content/detail/3834/Siaran+Pers+No.+17-PIH-KOMINFO$2-$

2014+tentang + Riset + Kominfo + dan + UNICEF + Mengenai + Perilaku + Anak + dan + Remaja + Dalam +Menggunakan+Internet+/0/siaran_pers, diakses tanggal 10 Februari 2017

[3] http://smp.labschool.upi.edu/2011/10/media-pembelajaran-berbasis-internet-e-learning/, diakses tanggal 10 Februari 2017

[4] https://tenjocity.wordpress.com/2012/05/30/media-pembelajaran-berbasis-internet/, diakses tanggal 10 Februari 2017

[5] Dharmawati, Penggunaan Media e-Learning Berbasis Edmodo Dalam Pembelajaran English for Business, QUERY: Jurnal Sistem Informas, QUERY: Jurnal Sistem Informasi, Vol 1, No. 1, April 2017

[6] Tigowati, E-Learning Berbasis Schoology dan Edmodo : Ditinjau dari Motivasi dan Belajar Siswa SMK, Elinvo (electronics, Informatics and Vocational Education), Vol 2, No 1, Mei 2017 [7] Sonalita Wiguna, Subiyanto, Keunggulan Learning Management System Edmodo Berbasis Smartphone Terhadap Komputer Pada Hasil Belajar Siswa, Jurnal Pendidikan Informatika dan Sains, Vol.7, No. 2, Desember 2018 